\begin{tabular}{|c|c|c|c|}
\hline Diterima: 02 Mei 2021 & Direvisi: 29 Juli 2021 & Disetujui: 30 Juli 2021 & Dipubikasi: 30 Juli 2021 \\
\hline
\end{tabular}

\title{
PENGARUH SUKU BUNGA TERHADAP BAGI HASIL DEPOSITO MUDHARABAHDENGAN MEDIASI RETURN ON ASSET (ROA)
}

\author{
Muhammad Arief ${ }^{1)}$ Rika Lidyah $\left.{ }^{2}\right)^{*}$ M. Iqbal $^{3)}$ \\ Fakultas Ekonomi dan Bisnis Islam \\ Universitas Islam Negeri Raden Fatah Palembang \\ *Korespondensi email : rikalidyah_uin@radenfatah.ac.id
}

\begin{abstract}
Abstrak
Penelitian ini bertujuan untuk mengetahui pengaruh Suku Bunga terhadap Bagi Hasil Deposito Mudharabah dengan Mediasi Return On Indonesia (ROA) Pada Bank. Umum Syariab di Indonesia pada tabun 2014-2018. Pemilihan sampel menggunakan metode purposive sampling, yaitu laporan keuangan triwulan pada 3 bank umum syariah di Indonesia. Teknik analisis yang digunakan regresi berganda dan sobelt test. Hasil penelitian secara parsial suku bunga berpengaruh positif terhadap bagi deposito mudharabah hasil sebesar 2,432 dengan nilai signifikansi 0,018, suku bunga berpengaruh negatif terbadap ROA sebesar -2,462 dengan nilai signifikansi 0,017. ROA berpengaruh negatif terhadap bagi hasil deposito mudharabah sebesar -9,737 dengan nilai signifikansi 0,000. Pengarub suku bunga terhadap bagi hasil deposito mudharabah dengan mediasi ROA termasuk dalam model partial mediation yang memiliki pengarub positif sebesar 0,1908 dengan nilai signifikansi 0,0182 serta didukung juga oleh uji sobel test dengan besar pengaruh 2,38667730 z-value > 1,96 dan angka signifikan pada one-tailed probability sebesar 0,00850070 p-value <0,05. Kesimpulan babwa suku bunga berpengaruh positif terhadap bagi hasil deposito mudharabah dan berpengaruh negatif terbadap $\mathrm{ROA}$. ROA berpengaruh negatif terhadap bagi hasil deposito mudharabah dan ROA juga dapat memediasi secara tidak. langsung antara suku bunga dan bagi hasil deposito mudharabah.
\end{abstract}

Kata Kunci: Suku Bunga, Return On Assset (ROA), Bagi hasil Deposito Mudharabah, Bank Umum Syariah

\section{THE EFFECT OF INTEREST RATE ON THE PROFIT SHARING OF MUDHARABAH DEPOSITS WITH MEDIATION RETURN ON Indonesia (ROA)}

\begin{abstract}
This study aims to determine the effect of Interest Rates on Profit Sharing of Mudharabah Deposits with the Mediation of Return On Indonesia (ROA) at Islamic Commercial Banks in Indonesia in 2014-2018. The sample selection used a purposive sampling method, namely the quarterly financial statements of 3 Islamic commercial banks in Indonesia. The analysis technique used is multiple regression and the Sobel test. The results of the study partially have a positive effect on interest rates for mudharabah deposits yields of 2.432 with a significance value of 0.018 , interest rates have a negative effect on $\mathrm{RO} A$ of -2.462 with a significance value of 0.017 . ROA has a negative effect on the profit-sharing of mudharabah deposits of -9.737 with a significance value of 0.000 . The effect of interest rates on profit sharing for mudharabah deposits with ROA mediation is included in the partial mediation model which has a positive effect of 0.1908 with a significance value of 0.0182 and is also supported by the Sobel test with a large effect of 2.38667730 z-value $>1.96$ and a significant number on the one-tailed probability of 0.00850070 pvalues $<0.05$. The conclusion is that interest rates have a positive effect on the profit-sharing of mudharabah deposits and have a negative effect on $\mathrm{RO} A$. ROA has a negative effect on profit sharing for mudharabah deposits and $\mathrm{RO} A$ can also indirectly mediate between interest rates and profit sharing for mudharabah deposits.
\end{abstract}

Keywords : Interest Rate, Return on Assets (ROA), Profit-Sharing of Mudharabah Deposits, Sharia Banks 
I-FINANCE: a Research Journal on Islamic Finance Vol.07 No. 01 Juni 2021 http//jurnal.radenfatah.ac.id/index.php/i-finance

Muhammad Arief, Rika Lidyah dan M. Iqbal.............Pengaruh Suku Bunga

\section{PENDAHULUAN}

Berkembangnya bank-bank syariah di Negara-Negara berpengaruh ke Indonesia. Perkembangan Undang-undang No.7 Tahun 1992 menjadi Undang-undang No. 10 Tahun 1998 tentang perbankan syariah merupakan langkah maju dalam perkembangan perbankan. Dalam Undang-Undang ini perbankan syariah diberikan perlakukan yang sama (equaltreatment) dengan perbankan konvensional. Padahal jika dilihat jumlahnya, ketika Undang-Undang itu disahkan, baru ada satu bank syariah. Disahkan Undang-Undang No. 10 Tahun 1998 telah membuka kesempatan lebih luas bagi bank syariah untuk berkembang. Menurut (Lemiyana, 2018) Bank syariah adalah lembaga keuangan atau perbankan yang operasional dan produknya dikembangkan berdasarkan pada Al-Quran dan Al-Hadist atau dengan kata lain, bank syariah adalah lembaga keuangan yang fungsi pokoknya memberikan kredit dan jasa-jasa dalam lalu lintas pembayaran dan peredaran uang.

\section{Gambar 1}

\section{Grafik Perkembangan Suku Bunga Secara Triwulan}

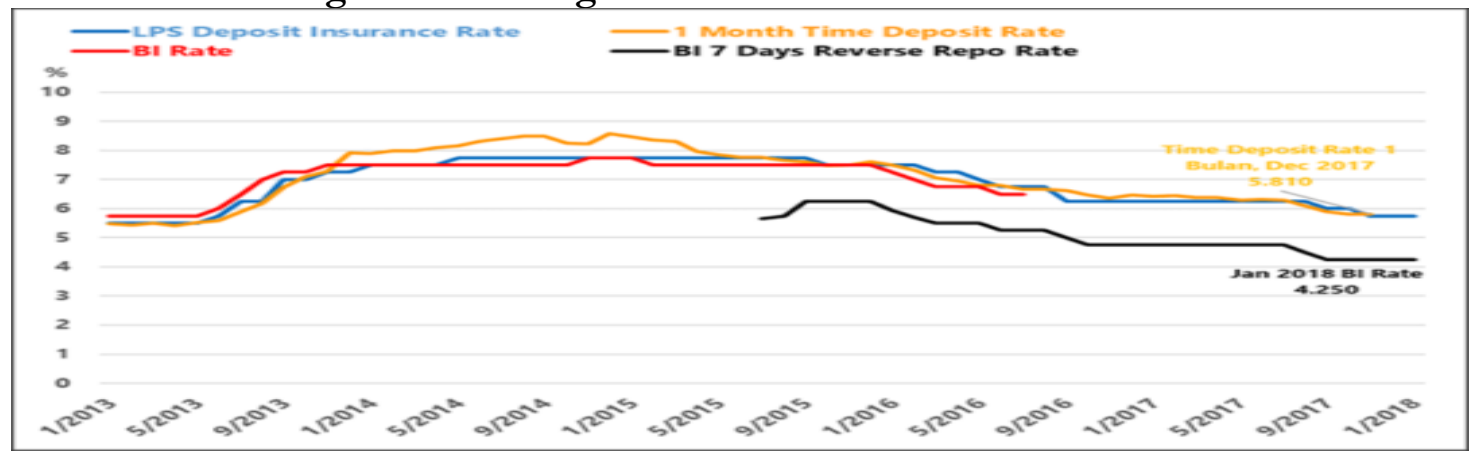

Gambar 1 menjelaskan bahwa perkembangan pada tingkat suku bunga mengalami penurunan dari tahun 2014 triwulan I hingga triwulan IV tahun 2018. Gubernur Bank Indonesia, Agus Martowardoyo, mengumumkan bahwa suku bunga acuan Bank Indonesia turun dari 4,75\% hingga sebesar 4,5\% pada tahun 2017 yang artinya suku bunga turun 0,25\% setiap tahunnya (Wirawan, n.d.). Head of Wealth Management \& Client Growht PT Bank Commonwealth Ivan Jaya juga mengatakan suku bunga mengalami penurunan yang signifikan dalam beberapa tahun terakhir yang akan berdampak bagi sebagian nasabah (Elena, n.d.).

Penurunan suku bunga ini memberikan sebuah peluang terhadap bank syariah yang tidak menggunakan sistem bunga seperti bank konvensional melainkan sistem bagi hasil. Jika dalam bank konvensional, suku bunga berdampak sangat besar. Apabila tingkat suku bunga naik maka orang-orang akan menabung di bank konvensional. Sebaliknya apabila tingkat suku bunga turun maka orang-orang akan menarik uang di tabungannya kemudian memindahkannya ke bank syariah karena dirasa memberikan untung yang lebih besar dari bank konvensional (Adetia, n.d.). Saat nasabah bank konvensional menarik uang tabungannya di saat itu juga peluang bank syariah meningkatkan sistem bagi hasil lebih besar dari sistem bunga di bank konvensional sehingga nasabah bank konvensional diharapkan beralih pada bank umum syariah.

Deposito mudharabah merupakan salah satu instrumen bank syariah dalam menarik minat nasabah agar mau menempatkan dananya di bank syariah, dengan mekanisme penyimpanan dana oleh nasabah bank syariah selama jangka waktu tertentu dengan menggunakan prinsip bagi hasil. Mudharabah adalah akad bagi hasil dimana pemilik dana (shabibul maal) menyediakan modal kepada pengelola dana (mudharib) untuk melakukan 
I-FINANCE: a Research Journal on Islamic Finance Vol.07 No. 01 Juni 2021 http//jurnal.radenfatah.ac.id/index.php/i-finance

Muhammad Arief, Rika Lidyah dan M. Iqbal.............Pengaruh Suku Bunga

aktivitas produktif dengan syarat keuntungan yang dihasilkan akan dibagi antara mereka menurut kesepakatan yang ditentukan sebelumnya dalam akad.

Pertumbuhan deposito mudharabah diukur dengan membandingkan jumlah deposito mudharabah dari waktu ke waktu, antara periode berjalan dengan periode sebelumnya. Jumlah deposito mudharabah berkaitan dengan kepercayaan nasabah untuk menyimpan dananya dengan mempertimbangakan profit yang akan diperoleh,sehingga diperkirakan pertumbuhannya bergantung pada beberapa faktor. (Ruslizar \& Rahmawaty, 2016)

Tabel 1

Pertumbuhan DPK pada Bank Umum Syariah Periode 2014-2018 (dalam milliar)

\begin{tabular}{cccccc}
\hline Triwulan & $\mathbf{2 0 1 4}$ & $\mathbf{2 0 1 5}$ & $\mathbf{2 0 1 6}$ & $\mathbf{2 0 1 7}$ & $\mathbf{2 0 1 8}$ \\
\hline I & 180,945 & 212,988 & 174,779 & 286,178 & 339,909 \\
\hline II & 191,594 & 213,477 & 177,051 & 302,613 & 341,216 \\
\hline III & 197,141 & 219,580 & 198,976 & 318,574 & 355,446 \\
\hline IV & 217,858 & 231,175 & 206,407 & 334,719 & 371,828 \\
\hline
\end{tabular}

Sumber : OJK, Statistik Perbankan Syariah (www.ojk.go.id)

Tabel 1 menunjukan bahwa dari tahun 2014-2018 mengalami pertumbuhan DPK yang signifikan yang awalnya hanya Rp.180.945.000.000,- pada tahun 2014 triwulan I, hingga DPK pada tahun 2018 triwulan IV menjadi sebesar Rp.371,828.000.000,-. Penyumbang DPK terbesar di bank umum syariah mayoritas deposito. DPK deposito di bank umum syariah menjadi sumber modal terbesar yang bisa mendapatkan profitabilitas yang tinggi dengan mengoptimalkan modal tersebut. Profitabilitas yang tinggi akan mendorong pada peningkatan sistem bagi hasil pada bank umum syariah. Sehingga dengan bagi hasil yang tinggi ini diharapkan menarik perhatian nasabah agar dapat berinvestasi pada produk bank syariah. Perbankan syariah mengalami peningkatan yang signifikan pada DPK per Oktober 2017. Tercatat pertumbuhan DPK sebesar 20,54\% year on year yang didominasi oleh deposito dengan komposisi 60,30\% dengan nominal Rp.192.420.000.000, (Yoliawan, n.d.). Peningkatan ini membuktikan bahwa DPK di bank umum syariah setiap tahun terus meningkat khususnya pada deposito hampir setengah dari DPK melakukan investasi di deposito. Statistik Perbankan Syariah (SPS) Mencatat pada tahun 2018 bulan Januari pertumbuhan nasabah bank syariah naik 18,05 \% pertahun. Sedangkan, Otoritas Jasa Keuangan (OJK) menyatakan bahwa Bank Konvensional Lebih rendah 4-5\% pertumbuhannya dibanding bank syariah yakni hanya mencapai 14\% pertahun (Wahyudi, n.d.). Orientasi dari bank adalah mendapatkan profitabilitas yang tinggi dengan memanfaatkan dengan maksimal total asset yang dimilikinya.

Return on Asset (ROA) merupakan salah satu rasio profitabilitas yang digunakan untuk mengukur efektifitas perusahaan didalam menghasilkan keuntungan dengan memanfaatkan total asset yang dimilikinya. ROA digunakan untuk mengukur efektifitas perusahaan didalam menghasilkan keuntungan dengan memanfaatkan total asset yang dimilikinya. Semakin tinggi rasio ini berarti perusahaan semakin efektif dalam memanfaatkan aktiva untuk menghasilkan laba bersih setelah pajak. Dengan demikian dapat disimpulkan bahwa semakin banyak ROA, berarti kinerja perusahaan semakin efektif, karena tingkat pengembalian akan semakin besar. Peningkatan daya tarik perusahaan menjadikan perusahaan tersebut semakin diminati investor, Karena dapat memberikan keuntungan (return) yang besar bagi investor. ROA sering sekali dipakai oleh manajemen puncak untuk mengevaluasi unit-unit bisnis di dalam suatu perusahaan multidivisional. Indikator profitabilitas yang berdasarkan ROA mempunyai keunggulan sebagai berikut: 
I-FINANCE: a Research Journal on Islamic Finance Vol.07 No. 01 Juni 2021 http//jurnal.radenfatah.ac.id/index.php/i-finance

Muhammad Arief, Rika Lidyah dan M. Iqbal.............Pengaruh Suku Bunga

1. Merupakan indikator pengukuran yang komprehensif untuk melihat keadaan suatu perusahaan berdasarkan laporan keuangan yang ada;

2. Mudah dihitung, dipahami dan sangat berarti dalam nilai absolute;

3. Merupakan denominator yang dapat diterapkan pada setiap unit organisasi yang bertanggung jawab terhadap profitabilitas dan unit usaha. (Ikhwal, 2016)

\section{Tabel 2}

\section{Rata-Rata ROA Secara Triwulan pada Bank Umum Syariah} Tahun 2014-2018

\begin{tabular}{cccccc}
\hline Trwiwuan & 2014 & 2015 & 2016 & 2017 & 2018 \\
\hline I & $0,37 \%$ & $0,69 \%$ & $0,88 \%$ & $1,12 \%$ & $1,23 \%$ \\
\hline II & $0,40 \%$ & $0,50 \%$ & $0,73 \%$ & $1,10 \%$ & $1,37 \%$ \\
\hline III & $0,39 \%$ & $0,49 \%$ & $0,59 \%$ & $1,00 \%$ & $1,41 \%$ \\
\hline IV & $0,41 \%$ & $0,49 \%$ & $0,63 \%$ & $0,63 \%$ & $1,28 \%$ \\
\hline
\end{tabular}

Sumber: OJK, (www.ojk.go.id) (Data diolah) 2021

Pada Tabel 2 menunjukan bahwa perkembangan ROA mengalami peningkatan dari 0,37\% pada tahun 2014 triwulan I hingga 1,28\% pada tahun 2018 triwulan IV. Peningkatan ROA ini juga akan dapat mempengaruhi bagi hasil di bank umum syariah. Semakin tinggi profitabilitas pada suatu bank umum syariah maka semakin besar juga sistem bagi hasil atas keuntungan (profitabilitas), sesuai dengan yang sudah disepakati oleh pihak nasabah dan pihak bank.

Bank yang sudah mempublikasikan laporan keuangan kuartal III-2017 mencatat rasio profitabilitas membaik ketimbang periode yang sama tahun 2016. Salah satunya terlihat dari perbaikan ROA. Ketujuh bank yang memiliki rata-rata ROA sampai September 2017 sebesar 2,58\%. Angka ini naik 7,5 basis poin (bps) dibanding September 2016. Semakin tinggi ROA berarti rasio profitabilitas bank semakin baik dari segi penggunaan asset (Yudistira, n.d.). Kejadian ini membuktikan bahwa profitabilitas pada bank syariah yang tinggi akan mempengaruhi bagi hasil sesuai kesepakatan antara pihak nasabah dan pihak bank atas keuntungan (profitabilitas) bank.

Secara teoritis, dapat dikatakan tidak ada keterkaitan antara tingkat suku bunga bank umum konvensional dengan tingkat profitabilitas bank umum syariah. Namun ketika dikaitkan dengan fenomena fluktuatif tabel ROA pada Bank Umum Syariah, hal ini tentu secara praktis sangat berkaitan dengan dinamika kebijakan tingkat suku bunga yang dikeluarkan oleh BI yang diiringi oleh pergerkan inflasi. Meskipun setiap tahunnya, grafik ROA Bank Umum Syariah mengalami kenaikan, namun grafik per triwulannya justru mengalami fluktuasi. Hal ini yang harus dicermati oleh Bank Syariah dengan menggunakan signaling theory sebagai landasan kebijakannya. Teori sinyal mengemukakan tentang bagaimana seharusnya sebuah perusahaan memberikan sinyal kepada pengguna laporan keuangan. Sinyal ini berupa informasi mengenai apa yang sudah dilakukan oleh manajemen untuk merealisasikan keinginan pemilik. Sinyal dapat berupa promosi atau informasi lain yang dapat menyatakan bahwa perusahaan tersebut lebih baik daripada perusahaan lain. Manajemen selalu berusaha untuk mengungkapkan informasi privat yang menurut pertimbangannya sangat diminati investor dan pemegang saham khususnya jika informasi tersebut merupakan berita baik (good news). Manajemen juga berminat menyampaikan informasi yang dapat meningkatkan kredibilitasnya dan kesuksesan perusahaan meskipun informasi tersebut tidak diwajibkan. Beberapa penelitian akademik menunjukkan semakin 
I-FINANCE: a Research Journal on Islamic Finance Vol.07 No. 01 Juni 2021 http//jurnal.radenfatah.ac.id/index.php/i-finance

Muhammad Arief, Rika Lidyah dan M. Iqbal.............Pengaruh Suku Bunga

besar perusahaan makin banyak informasi sukarela yang disampaikan. Pengungkapan yang bersifat sukarela merupakan sinyal positif bagi perusahaan. (Nuswandari, 2009)

Berbanding lurus dengan penelitian ini, teori sinyal berguna agar menampilkan rasio keuangan pada laporan keuangan agar pengguna laporan keuangan tertarik berinvestasi. Rasio keuangan ROA pada suatu bank umum syariah yang tinggi menunjukan kinerja bank itu baik dan profitabilitas bank tersebut tinggi (Levia \& Sulasmiyati, 2017), sehingga dengan profitabilitas tinggi itu memperbesar nisbah bagi hasil deposito mudharabah. Pengguna laporan keuangan akan tertarik untuk melakukan investasi apabila suatu bank umum syariah memiliki rasio keuangan yang tinggi atau besar di laporan keuangannya. Hal inilah yang menyebabkan perlu dilakukannya penelitian dengan mempertimbangkan ROA sebagai mediasi antara tingkat suku bunga dan bagi hasil deposito mudharabah. Adanya reseach gap dari beberapa penelitian sebelumnya juga menjadi faktor penguat bagi peniliti untuk menjadikan ROA sebagai variabel intervening antara variabel independen yaitu tingkat suku bunga dan variabel dependen yaitu bagi hasil deposito mudharabah.

Penelitian terkait hubungan antara suku bunga dan bagi hasil deposito mudharabah yang dilakukan oleh (Sunaryo \& Isna K, 2012) menunjukan adanya pengaruh positif dan signifikan terhadap antara keduanya. Berbanding terbalik dengan penelitian yang dilakukan oleh (Cahyani et al., 2018) bahwa suku bunga tidak berpengaruh terhadap bagi hasil deposito mudharabah. Adapun penelitian terkait pengaruh suku bunga terhadap ROA yang dilakukan oleh (Kalengkongan, 2013) menunjukkan bahwa adanya pengaruh signifikan terhadap ROA, namun penelitian dari (Syaichu, 2013) justru menunjukan bahwa suku bunga tidak mempengaruhi ROA. Sedangkan penelitian yang dilakukan oleh (Laily, 2018) menunjukan bahwa ROA berpengaruh negatif terhadap bagi hasil deposito mudharabah, berbeda dengan penelitian dari (Nur \& Nasir, 2014) yang mengemukakan bahwa ROA berpengaruh signifikan positif terhadap bagi hasil deposito mudharabah.

Dengan adanya beberapa reseach gap dari penelitian sebelumnya, maka perlu diadakan penelitian lanjutan terkait Pengaruh Suku Bunga Terhadap Bagi Hasil Deposito Mudharabah dengan Mediasi Return On Asset (ROA). Penelitian ini membahas mengenai permasalahan apakah variabel suku bunga berpengaruh terhadap bagi hasil deposito dan ROA? Dan apakah ROA berpengaruh terhadap bagi hasil deposito sehingga dapat memediasi pengaruh antara suku bunga dan bagi hasil deposito? Maka tujuan penelitian ini untuk mengetahui pengaruh suku bunga terhadap bagi hasil deposito dan ROA serta bagaimana pengaruh ROA terhadap bagi hasil deposito, sehingga dapat pula diketahui apakah mediasi dari ROA terhadap suku bunga dan bagi hasil dapat dilakukan atau tidak.

\section{METODE PENELITIAN}

\section{Jenis Dan Pendekatan Penelitian}

Desain penelitian yang digunakan dalam penelitian ini adalah tipe kausalitas dengan pendekatan kuantitatif. Desain penelitian kausalitas adalah penelitian yang mencari hubungan pengaruh akibat dan sebab variabel independen yang mempengaruhi $\mathrm{X}$ terhadap variabel dependen yang mempengaruhi Y. (Sugiyono, 2018)

\section{Sumber dan Pengolahan Data}

Sumber data dalam penelitian ini adalah data sekunder yang didownload dari website resmi bank umum syariah berupa laporan keuangan secara triwulanan di Indonesia. Data suku bunga diperoleh dari publikasi oleh Bank Indonesia melalui website resminya. Adapun progam pengolahan data menggunakan program SPSS versi 21. 
I-FINANCE: a Research Journal on Islamic Finance Vol.07 No. 01 Juni 2021 http//jurnal.radenfatah.ac.id/index.php/i-finance

Muhammad Arief, Rika Lidyah dan M. Iqbal.............Pengaruh Suku Bunga

\section{Populasi Dan Sampel}

Populasi dapat diartikan sebagai wilayah generalisasi yang terdiri atas : obyek/subyek yang mempunyai kualitas dan karakteristik tertentu yang ditetapkan oleh peneliti untuk dipelajari dan kemudian ditarik kesimpulan (Sugiyono, 2018). Populasi dalam penelitian ini yaitu semua bank-bank syariah yang resmi terdaftar di Bank Indonesia yang sampai saat ini ada 14 bank syariah. Sampel adalah sebagian dari populasi (Sugiyono, 2018). Sampel penelitian ini menggunakan purposive sampling dengan kriteria sebagai berikut:

1. Bank umum syariah yang terdaftar di otoritas jasa keuangan (OJK).

2. Bank umum syariah yang terdapat publikasi laporan keuangan berupa triwulan, antara triwulan I sampai triwulan IV yang dipublikasikan secara lengkap di masing-masing website bank syariah yang berkaitan pada tahun 2014-2018.

3. Bank umum syariah yang memiliki data rasio keuangan terkait pengukuran di penelitian ini berupa variabel independen dan dependen.

4. Bank umum syariah yang memiliki nilai bagi hasil deposito mudharabah yang stabil lebih dari $>5 \%$ dari tahun 2014-2018 serta lebih besar dari bank umum syariah lainnya

5. Bank umum syariah yang memiliki nilai ROA yang stabil dari $0,05-1.25 \%$ yang menunjukan bahwa ROA dikatakan cukup baik.

Berdasarkan kriteria penentuan sampel diatas maka terdapat 3 bank umum syariah yaitu Bank BCA Syariah, Bank BRI Syariah, dan Bank BNI Syariah.

\section{Variabel Penelitian}

Variabel penelitian adalah segala sesuatu apa saja yang ditetapkan oleh peneliti untuk dipelajari sehingga diperoleh informasi tentang hal tersebut, kemudian ditarik kesimpulan (Sugiyono, 2018). Variabel yang digunakan dalam penelitian dapat diklasifikasikan menjadi:1. Variabel bebas (independent) yaitu variabel yang berfungsi menerangkan atau mempengaruhi variabel dependen (terikat). Variabel yang digunakan dalam penelitian dapat diklasifikasikan menjadi:

1. Variabel bebas (independent): suku bunga $(\mathrm{X})$

2. Variabel perantara (intervening/mediasi): return on asset (ROA) (M)

3. Variabel terikat (dependent): bagi hasil deposito mudharabah (Y)

\section{Teknik Analisis}

\section{Analisis Jalur (Path Analysis)}

Analisis jalur (path analysis) merupakan pengembangan analisis regresi ganda yang menguraikan besaran pengaruh dari variabel bebas terhadap variabel terikat secara tidak langsung. Metode analisis ini berguna agar apabila bertemu dengan masalah penelitian yang memiliki hubungan antar sebab akibat sehingga dapat menerangkan langsung dan tidak langsung seperangkat variabel, sebagai variabel penyebab terhadap variabel lainnya yang merupakan akibat. Variabel intervening merupakan variabel antara atau mediasi, fungsinya memediasi pengaruh variabel independen terhadap variabel dependen. Untuk menguji pengaruh variabel intervening digunakan metode analisis jalur.

\section{Analisis Variabel Mediasi (Versi Baron dan Kenny)}

Analisis variabel mediasi Baron dan Kenny yang lebih dikenal dengan strategy casual step, memiliki tiga persamaan regresi yang harus diestimasi yaitu :

1. Persamaan regresi sederhana variabel mediator $(\mathrm{M})$ pada variabel independen $(\mathrm{X})$ yang digarapkan variabel indenpenden signifikan mempengaruhi variabel mediator, jadi koefisien $a \neq 0$. 
2. Persamaan regresi sederhana variabel dependen $(\mathrm{Y})$ pada variabel independen $(\mathrm{X})$ yang diharapkan variabel independen harus signifikan mempengaruhi variabel, jadi koefisien $c \neq 0$.

Persamaan regresi berganda variabel dependen $(Y)$ pada variabel independen $(X)$ dan mediator (M) yang diharapkan variabel mediator signifikan mempengaruhi variabel dependen, jadi koefisisen $\mathrm{b} \neq 0$. Mediasi terjadi jika pengaruh variabel independen terhadap dependen lebih rendah pada persamaan ketiga(c') dibandingkan pada persamaan kedua (c).

\section{HASIL PENELITIAN DAN PEMBAHASAN}

\section{Hasil Penelitian}

\section{Analisis Substruktural I}

\section{Gambar 2}

Analisis struktural I dapat digambarkan sebagai berikut.

\section{Model Struktural I}

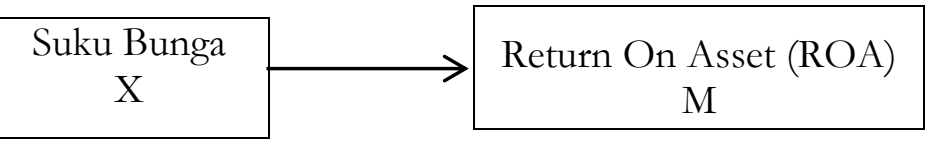

Berdasarkan gambar tersebut, maka dapat dibuat persamaan struktural I sebagai berikut.

$\mathrm{M}(\mathrm{ROA})=\mathrm{SUKU} B U N G A=\mathrm{e}_{1}$ .(Persamaan Struktural 1)

\section{Tabel 3}

Berdasarkan pengolahan data diperoleh hasil sebagai berikut.

\section{Pengaruh Suku Bunga Secara Simultan Terhadap ROA}

\begin{tabular}{lrrrr}
\hline Model & $\mathrm{R}$ & $\mathrm{R}$ Square & \multicolumn{1}{c}{ Adjusted R Square } & \multicolumn{1}{l}{ Std. Error of the Estimate } \\
\hline 1 & $.308^{\mathrm{a}}$ & .095 & .079 & .34760 \\
\hline
\end{tabular}

Sumber : data sekunder yang diolah, 2021

Tabel 3 di atas menunjukkan besarnya angka $R$ square $\left(R^{2}\right)$ adalah 0,095. Angka tersebut memiliki penjelasan bahwa pengaruh suku bunga terhadap ROA secara simultan adalah $9,5 \%$.

Kelayakan model regresi digambarkan dengan angka-angka dari tabel ANOVA, sebagai berikut.

\section{Tabel 4}

\section{ANNOVA}

\begin{tabular}{llrrrrr}
\hline \multicolumn{1}{l}{ Model } & Sum of Squares & Df & Mean Square & F & \multicolumn{1}{c}{ Sig. } \\
\hline \multirow{3}{*}{1} & Regression & .732 & 1 & .732 & 6.060 & $.017^{\mathrm{b}}$ \\
\cline { 2 - 8 } & Residual & 7.008 & 58 & .121 & & \\
\cline { 2 - 8 } & Total & 7.740 & 59 & & & \\
\hline
\end{tabular}

Sumber : data sekunder yang diolah, 2021

Jika $F_{\text {hitung }}>F_{\text {tabel, }}$ maka Ho ditolak dan Ha diterima dan sebaliknya jika $F_{\text {hitung }}<$ $\mathrm{F}_{\text {tabel, }}$ maka Ho diterima dan Ha ditolak. Ketentuan nilai $\mathrm{F}_{\text {tabel }} \alpha=0,05, \mathrm{df}_{1}=(\mathrm{k}-1)$ atau $(2-1)$ 
I-FINANCE: a Research Journal on Islamic Finance Vol.07 No. 01 Juni 2021 http//jurnal.radenfatah.ac.id/index.php/i-finance

Muhammad Arief, Rika Lidyah dan M. Iqbal.............Pengaruh Suku Bunga

dan $\mathrm{df}_{2}=(\mathrm{n}-\mathrm{k})$ atau $(60-2=58)$ sehingga didapatkan nilai $\mathrm{F}_{\text {tabel }}$ sebesar 4,01. Hasil perhitungan diperoleh angka, $F_{\text {hitung }}$ sebesar 6,060 $>F_{\text {tabel }}$ sebesar 4,01. Dengan demikian bahwa model regresi tersebut sudah layak dan benar. Sehingga Ho ditolak dan Ha diterima artinya bahwa suku bunga secara simultan mempengaruhi ROA dengan besar pengaruh sebesar 9,5\% dan dengan nilai signifikan $0,017<\alpha=0,05$. Besaran pengaruh variabel lain diluar model regresi tersebut dihitung dengan rumus: $\left(1-r^{2}\right)$ atau $(1-0,095=0,905)$ atau sebesar $90,5 \%$.

\section{Analisis Substruktural II}

Gambar 3

Analisis struktural II dapat digambarkan sebagai berikut.

\section{Model Strukural II}

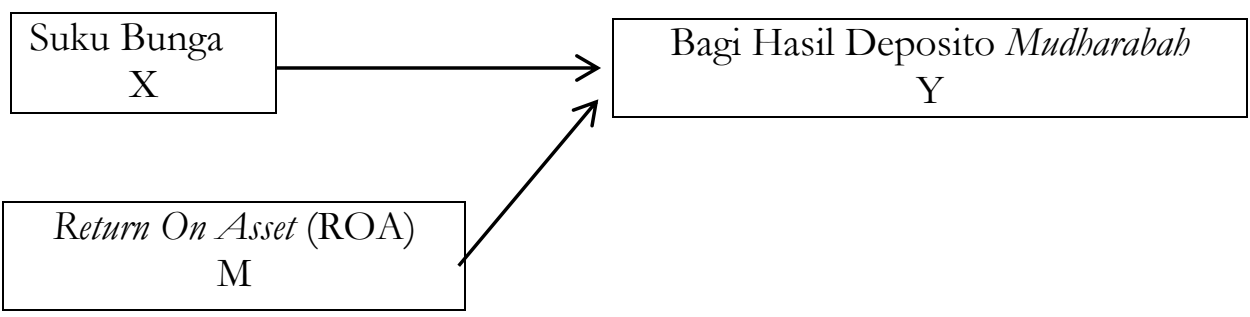

Berdasarkan gambar tersebut, maka dapat dibuat persamaan struktural I sebagai berikut.

$\mathrm{Y}($ Bagi Hasil $)=\beta$ suku Bunga $+\beta \mathrm{ROA}+\mathrm{e}_{1} \ldots \ldots \ldots \ldots \ldots \ldots \ldots \ldots($ Persamaan Struktural 2$)$

Berdasarkan pengolahan data diperoleh hasil sebagai berikut.

\section{Tabel 6}

\section{Model Summary}

\begin{tabular}{lllll}
\hline Model & R & R Square & Adjusted R Square & Std. Error of the Estimate
\end{tabular}

\begin{tabular}{|c|c|c|c|c|}
\hline 1 & $.831^{a}$ & 691 & & .76299 \\
\hline
\end{tabular}

Tabel 6 menunjukkan besarnya angka $R$ square $\left(R^{2}\right)$ adalah 0,691. Angka tersebut memiliki penjelasan bahwa pengaruh suku bunga dan ROA terhadap bagi hasil deposito mudharabah secara simultan adalah 69,1\%. berikut ini

Kelayakan model regresi digambarkan dengan angka-angka dari tabel ANOVA

\section{Tabel 7}

\section{ANNOVA}

\begin{tabular}{llrrrrr}
\hline \multicolumn{1}{l}{ Model } & Sum of Squares & Df & Mean Square & F & \multicolumn{1}{c}{ Sig. } \\
\hline \multirow{3}{*}{1} & Regression & 74.129 & 2 & 37.064 & 63.668 & $.000^{\mathrm{b}}$ \\
\cline { 2 - 8 } & Residual & 33.183 & 57 & .582 & & \\
\cline { 2 - 8 } & Total & 107.311 & 59 & & & \\
\hline
\end{tabular}

Sumber : Data sekunder yang diolah, 2021 
I-FINANCE: a Research Journal on Islamic Finance Vol.07 No. 01 Juni 2021 http//jurnal.radenfatah.ac.id/index.php/i-finance

Muhammad Arief, Rika Lidyah dan M. Iqbal.............Pengaruh Suku Bunga

Jika $\mathrm{F}_{\text {hitung }}>\mathrm{F}_{\text {tabel, }}$ maka Ho ditolak dan Ha diterima dan sebaliknya jika $\mathrm{F}_{\text {hitung }}<$ $\mathrm{F}_{\text {tabel}}$, maka Ho diterima dan Ha ditolak. Ketentuan nilai $\mathrm{F}_{\text {tabel }} \alpha=0,05, \mathrm{df}_{1}=(\mathrm{k}-1)$ atau (3-1) dan $\mathrm{df}_{2}=(\mathrm{n}-\mathrm{k})$ atau $(60-3=57)$ sehingga didapatkan nilai $\mathrm{F}_{\text {tabel }}$ sebesar 3,16. Hasil perhitungan diperoleh angka, $F_{\text {hitung }}$ sebesar 63,668 $>F_{\text {tabel }}$ sebesar 3,16. Dengan demikian bahwa model regresi tersebut sudah layak dan benar. Sehingga Ho ditolak dan Ha diterima artinya bahwa suku bunga dan ROA secara simultan mempengaruhi bagi hasil deposito mudharabah dengan besar pengaruh sebesar $69,1 \%$ dan dengan nilai signifikan $0,000<\alpha=$ 0,05 . Besaran pengaruh variabel lain diluar model regresi tersebut dihitung dengan rumus: $\left(1-r^{2}\right)$ atau $(1-0,691=0,309)$ atau sebesar 30,9\%.

\section{Tabel 8}

\section{Coefficients $^{\mathrm{a}}$}

\begin{tabular}{lrrrrrr}
\hline \multirow{2}{*}{ Model } & \multicolumn{2}{c}{$\begin{array}{c}\text { Unstandardized } \\
\text { Coefficients }\end{array}$} & \multicolumn{2}{c}{$\begin{array}{c}\text { Standardized } \\
\text { Coefficients }\end{array}$} & T & Sig. \\
\cline { 2 - 5 } & \multicolumn{1}{c}{$\mathrm{B}$} & Std. Error & Beta & & \\
\hline (Constant) & 7.379 & .638 & & 11.558 & .000 \\
\hline 1 SUKU BUNGA $(\mathrm{X})$ & .191 & .078 & .188 & 2.432 & .018 \\
\hline RETURN ON ASSET $(\mathrm{M})$ & -2.806 & .288 & -.754 & -9.737 & .000 \\
\hline
\end{tabular}

Sumber : Data sekunder yang diolah, 2021

Jika thitung $>\mathrm{t}_{\text {tabel, }}$ maka Ho ditolak dan Ha diterima dan sebaliknya jika $\mathrm{t}_{\text {hitung }}<\mathrm{t}_{\text {tabel, }}$ maka Ho diterima dan Ha ditolak. Ketentuan angka $\mathrm{t}_{\text {tabel }} \alpha=0,05 \mathrm{dan} \mathrm{df}=(\mathrm{n}-\mathrm{k})$ atau $(60-3)$ $=57$. Sehingga didapatkan nilai tabel sebesar 1,67203.

1. Pengaruh suku bunga terhadap bagi hasil deposito mudharabah. Berdasarkan hasil perhitungan maka didapatkan angka $t_{\text {hitung }}$ sebesar 2,432 $>t_{\text {tabel }}$ sebesar 1,67203, sehingga Ho ditolak dan Ha diterima artinya bahwa ada pengaruh suku bunga terhadap bagi hasil deposito mudharabah yang memiliki pengaruh positif. Pengaruh suku bunga terhadap bagi hasil deposito mudarabah sebesar $=0,188$ atau $18,8 \%$ dan dianggap signifikan dengan angka $0,018<0,05$.

2. Pengaruh ROA terhadap bagi hasil deposito mudharabah. Berdasastkan hasil perhitungan maka didapatkan angka $t_{\text {hitung }}$ sebesar $-9,737>t_{\text {tabel }}$ sebesar 1,67203, sehingga Ho ditolak dan $\mathrm{Ha}$ diterima artinya bahwa ada pengaruh ROA terhadap bagi hasil deposito mudharabah yang memiliki pengaruh negative. Pengaruh ROA terhadap bagi hasil deposito mudarabah sebesar $=-0,754$ dan dianggap signifikan dengan angka $0,000<$ 0,05 .

\section{Pengujian Variabel Mediasi}

Strategi Causal Step (Pengaruh Suku Bunga terhadap Bagi Hasil Deposito Mudharabah dengan Mediasi Return On Asset) berikut.

Berdasarkan pengolahan data, maka dapat digambarkan strategi causal step sebagai 
I-FINANCE: a Research Journal on Islamic Finance Vol.07 No. 01 Juni 2021

http//jurnal.radenfatah.ac.id/index.php/i-finance

Muhammad Arief, Rika Lidyah dan M. Iqbal.............Pengaruh Suku Bunga

\section{Gambar 4}

\section{Strategi Causal Step}

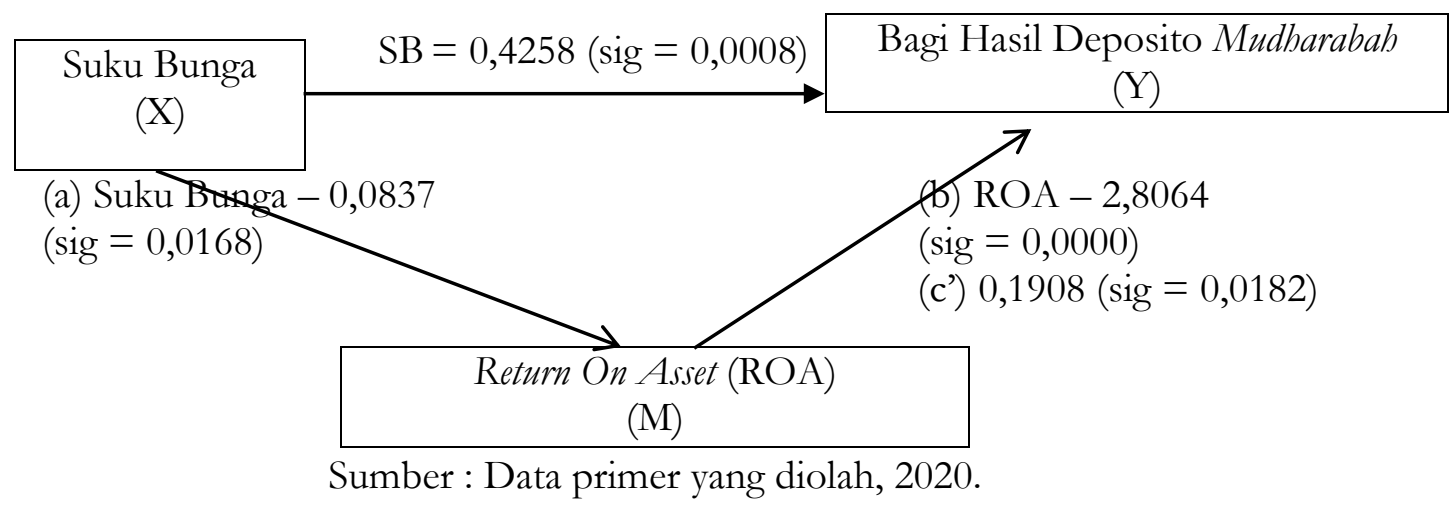

Berdasarkan gambar di atas, maka dapat disusun persamaan sebagai berikut.

$\mathrm{Y}=\beta$ SUKU BUNGA $+\beta R O A+\mathrm{e} \ldots \ldots \ldots \ldots \ldots \ldots \ldots \ldots \ldots \ldots .($ Persamaan Struktural 3$)$

Tiga persamaan yang harus diestimasi dalam strategi causal step :

1. Persamaan regresi sederhana variabel intervening ROA $(M)$ pada variabel independen suku bunga $(\mathrm{X})$. Hasil analisis didapatkan bukti bahwa suku bunga signifikan terhadap ROA dengan nilai singnifikan $0,0168<\alpha=0,05$ dan nilai koefisien regresi (a) $=$ 0,0837 .

2. Persamaan regresi sederhana variabel dependen bagi hasil deposito mudharabah (Y) pada variabel indepnden suku bunga $(\mathrm{X})$. Hasil analisis didapatkan bukti bahwa suku bunga signifikan terhadap bagi hasil deposito mudharabah dengan nilai sig $0,0008<\alpha=0,05$ dan nilai koefisien regresi $(\mathrm{c})=0,4258$.

3. Persamaan regresi berganda variabel dependen bagi hasil deposito mudharabah (Y) pada variabel suku bunga $(\mathrm{X})$ serta variabel intervening ROA $(\mathrm{M})$. Hasil analisis ditemukan bukti bahwa ROA signifikan terhadap bagi hasil deposito mudharabah, setelah mengontrol suku bunga dengan nilai signifikan $0,0000<\alpha=0,05$ dan koefisien regresi (b) $=-2,8064$. Selanjutnya ditemukan direct effect c' sebesar 0,1908 yang berarti lebih kecil dari $\mathrm{c}=0,4258$. Pengaruh variabel independen suku bunga terhadap variabel dependen bagi hasil deposito mudharabah berkurang dengan signifikan $0,0008<\alpha=$ 0,05 setelah mengontrol variabel intervening ROA. Didapatkan sebuah kesimpulan bahwa model ini termasuk ke dalam partial mediation atau terjadi mediasi, dimana variabel suku bunga dapat mempengaruhi secara langsung pada variabel bagi hasil deposito mudharabah ataupun secara tidak langsung dengan melibatkan variabel intervening ROA atau bisa dikatakan bahwa ROA mampu memediasi antara hubungan suku bunga terhadap bagi hasil deposito mudharabah.

\section{Pengujian Sobel Test (Pengaruh Suku Bunga terhadap Bagi Hasil Deposito Mudharabah dengan Mediasi Return On Asset).}

Uji sobel test ini dinilai lebih mempunyai kekuatan secara statistik dari pada metode formal lainnya termasuk pendekatan Baron dan Kenny (Preacher dan Hayes, 2004 : 719. Sehingga uji sobel test ini berguna agar mendukung hasil dari strategi causal step.

Koefisien antara variabel suku bunga dan variabel intervening ROA (A). 
I-FINANCE: a Research Journal on Islamic Finance Vol.07 No. 01 Juni 2021 http//jurnal.radenfatah.ac.id/index.php/i-finance

Muhammad Arief, Rika Lidyah dan M. Iqbal.............Pengaruh Suku Bunga

Tabel 9

Koefisien Suku Bunga terhadap ROA

\begin{tabular}{cc}
\hline Model & Coefficients \\
\hline Suku Bunga & $-0,0837$ \\
\hline Sumber : Data sekunder yang diolah, 2021
\end{tabular}

Koefisien antara variabel intervening ROA dan variabel dependen bagi hasil deposito mudharabah (B).

Tabel 10

Koefisien ROA terhadap Bagi Hasil Deposito Mudharabah

\begin{tabular}{cc}
\hline Model & Coefficients \\
\hline ROA & $-2,8064$
\end{tabular}

Sumber : Data sekunder yang diolah, 2021

Hasil analisis dengan Sobel Test Calculator For The Signification Of Mediation Kris Preacher :

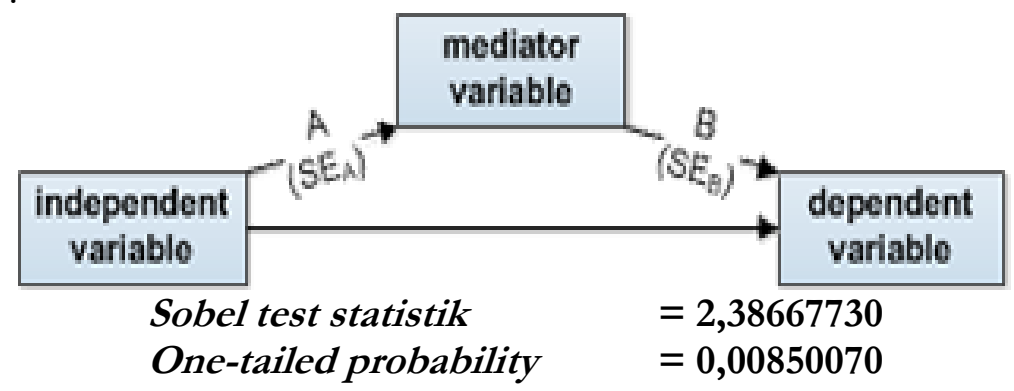

Hasil analisis dengan menggunakan sobel test menunjukan nilai statistic (z-value) untuk pengaruh variabel ROA sebagai variabel intervening antara variabel suku bunga terhadap variabel bagi hasil deposito mudharabah $(2,38667730)$ dan angka signifikan pada one-tailed probability sebesar 0,00850070. Karena z-value $>1,96$ atau p-value $<0,05$. Maka dapat ditarik kesimpulan bahwa indirect effect atau pengaruh secara tidak langsung signifikan. Ini menunjukan bahwa hasilnya sama dengan strategi causal step, sehingga hipotesis mediasi mendukung atau dapat diterima.

\section{Pembahasan}

\section{Pengaruh Suku Bunga terhadap Bagi Hasil Deposito Mudharabah}

Hipotesis pertama yang diajukan menyatakan bahwa suku bunga berpengaruh positif terhadap bagi hasil deposito mudharabah. Berdasarkan hasil penelitian diperoleh bahwa nilai $t_{\text {hitung }}$ sebesar 2,432 $>\mathrm{t}_{\text {tabel }}$ sebesar 1,67203, sehingga Ho ditolak dan Ha diterima artinya bahwa ada pengaruh suku bunga terhadap bagi hasil deposito mudharabah yang memiliki pengaruh positif. Pengaruh suku bunga terhadap bagi hasil deposito mudarabah sebesar $=0,191$ atau 19,1\% dan dianggap signifikan dengan angka 0,018 $<0,05$. Hasil pengujian hipotesis ini sesuai dengan pengembangan hipotesis yang menyatakan bahwa suku bunga berpengaruh positif terhadap bagi hasil deposito mudharabah. 
I-FINANCE: a Research Journal on Islamic Finance Vol.07 No. 01 Juni 2021 http//jurnal.radenfatah.ac.id/index.php/i-finance

Muhammad Arief, Rika Lidyah dan M. Iqbal.............Pengaruh Suku Bunga

Ini menunjukan bahwa ketika suku bunga mengalami kenaikan maka bagi hasil deposito mudharabah akan ikut naik karena seiring suku bunga mengalami kenaikan maka bunga di bank umum konvensional akan ikut naik juga yang dapat menarik perhatian nasabah yang akan berinvestor beralih ke bank umum konvensional karena keuntungan yang lebih besar ketika suku bunga mengalami kenaikan. Sehingga dengan kenaikan suku bunga maka bank umum syariah akan menaikan juga nisbah bagi hasil agar dapat bersaing dengan bank umum konvensional dan menarik perhatian nasabah untuk berinvestor di bank umum syariah dengan nisbah bagi hasil yang besar.

Hasil penelitian ini sejalan dengan penelitian yang dilakukan oleh (Farianto, 2014) menyatakan bahwa suku bunga berpengaruh positif dan signifikan terhadap bagi hasil deposito mudharabah dan penelitian (Sunaryo \& Isna K, 2012) juga menyatakan bahwa suku bunga berpengaruh positif dan signifikan terhadap bagi hasil deposito mudharabah.

\section{Pengaruh Suku Bunga terhadap Return On Asset (ROA).}

Hipotesis kedua yang diajukan menyatakan bahwa suku bunga berpengaruh negatif terhadap return on asset (ROA). Berdasarkan hasil penelitian diperoleh bahwa nilai thitung sebesar -2,462 $>t_{\text {tabel }}$ sebesar 1,67155, sehingga Ho ditolak dan Ha diterima artinya bahwa ada pengaruh suku bunga terhadap ROA yang memiliki pengaruh negatif dan dianggap signifikan dengan angka $0,017<\alpha=0,05$. Hasil pengujian hipotesis ini sesuai dengan pengembangan hipotesis yang menyatakan bahwa suku bunga berpengaruh negatif terhadap return on asset (ROA).

Ini menunjukan bahwa ketika suku bunga mengalami kenaikan maka ROA akan mengalami penurunan karena ketika suku bunga mengalami kenaikan maka nasabah akan berlomba-lomba berinvestasi pada bank umum konvensional karena lebih menguntungkan ketika suku bunga mengalami kenaikan. Sehingga dengan banyaknya nasabah yang berinvestasi pada bank umum konvensional maka DPK bank umum syariah akan ikut menurun sehingga bank umum syariah sulit untuk mengelola dana karena minimnya dana tersebut, membuat ROA bank umum syariah akan otomatis ikut menurun.

Hasil penelitian ini diperkuat dengan adanya penelitian yang di lakukan oleh (Alim, 2014) menyatakan bahwa suku bunga berpengaruh negatif dan signifikan terhadap return on asset (ROA) dan penelitian (Oktavia Rosana, 2018) juga menyatakan bahwa suku bunga berpengaruh negatif dan signifikan terhadap return on asset (ROA).

\section{Pengaruh Return On Asset (ROA) terhadap Bagi Hasil Deposito Mudharabah}

Hipotesis kedua yang diajukan menyatakan bahwa return on asset (ROA) berpengaruh negatif terhadap Bagi Hasil Deposito Mudharabah. Berdasarkan hasil penelitian diperoleh bahwa nilai $t_{\text {hitung }}$ sebesar $-9,737>t_{\text {tabel }}$ sebesar 1,67203, sehingga Ho ditolak dan Ha diterima artinya bahwa ada pengaruh ROA terhadap bagi hasil deposito mudharabah yang memiliki pengaruh negatif dan dianggap signifikan dengan angka $0,000<0,05$.

Ini menunjukan bahwa ketika ROA mengalami kenaikan maka bagi hasil deposito mudharabah akan mengalami penurunan karena saat ROA mengalami kenaikan maka akan diringi oleh pajak yang besar juga dan ROA pada bank umum syariah tidak dialokasikan seluruh pada produk bagi hasil deposito mudharabah melainkan ROA juga harus melakukan kewajiban dalam pembayaran likuiditas-likuiditas lainya maupun membayar keperluan operasional bank umum syariah itu sendiri.

Hasil penelitian ini diperkuat dengan adanya penelitian yang di lakukan oleh (Laily, 2018) menyatakan bahwa ROA berpengaruh negatif dan signifikan terhadap bagi hasil 
I-FINANCE: a Research Journal on Islamic Finance Vol.07 No. 01 Juni 2021 http//jurnal.radenfatah.ac.id/index.php/i-finance

Muhammad Arief, Rika Lidyah dan M. Iqbal.............Pengaruh Suku Bunga

deposito mudharabah. (Prasetyaningrum, 2016) juga menyatakan bahwa ROA berpengaruh negatif dan signifikan terhadap bagi hasil deposito mudharabah.

\section{Pengaruh Suku Bunga terhadap Bagi Hasil Deposito Mudharabah dengan mediasi Return On Asset (ROA)}

Hipotesis kedua yang diajukan menyatakan bahwa suku bunga berpengaruh positif terhadap bagi hasil deposito mudharabah dengan return on asset (ROA) sebagai variabel mediasi. Berdasarkan hasil penelitian diperoleh bahwa nilai c sebesar 0,4258 dan nilai direct effect c' sebesar 0,1908 ini menunjukan bahwa terjadi partial mediation karena c' $<\mathrm{c}$ dan dianggap signifikan dengan angka 0,0182<0,05.

Ini Menunjukan bahwa terjadi mediasi, dimana variabel suku bunga dapat mempengaruhi secara langsung pada variabel bagi hasil deposito mudharabah ataupun secara tidak langsung dengan melibatkan variabel intervening ROA atau bisa dikatakan bahwa ROA mampu memediasi antara hubungan suku bunga terhadap bagi hasil deposito mudharabah.

\section{KESIMPULAN}

Penelitian ini menemukan bahwa terdapat suku bunga berpengaruh positif terhadap bagi hasil deposito mudharabah dan berpengaruh negatif terhadap ROA. Dapat diartikan bahwa ketika suku bunga naik maka bank umum syariah akan meningkatkan nisbah bagi hasil deposito mudharabah agar dapat bersaing dengan bank umum konvensional. Sebab disaat bersamaan, nasabah bank umum syariah cednderung akan beralih kepada bank umum konvensional yang lebih menguntungkan. Adapun ROA berpengaruh negatif terhadap bagi hasil deposito mudharabah, karena ketik ROA naik akan diiringi dengan pajak yang besar. Sedangkan ROA tidak sepenuhnya dialokasikan pada produk deposito mudharabah melainkan juga harus melakukan kewajiban membayar likuiditas-likuiditas seperti memenuhi operasional bank. Sehingga, ROA yang tinggi cenderung akan berdampak pada penurunan bagi hasil deposito mudharabah. Namun ROA dapat memediasi suku bunga terhadap bagi hasil deposito mudharabah secara tidak langsung. Ini menunjukan bahwa ketika suku bunga mengalami kenaikan akan mempengaruhi ROA yang meningkat juga apabila bank umum syariah dapat memberikan inovasi atau solusi agar nasabah bertahan dalam berinvestasi di bank umum syariah sehingga akan mendapatkan ROA yang tinggi. ROA yang tinggi akan meningkatkan bagi hasil deposito mudharabah karena sesuai akad antara pihak nasabah dan pihak bank umum syariah, oleh karena itu suku bunga berpengaruh positif dan signifikan terhadap bagi hasil deposito mudharabah dengan mediasi ROA.

Bagi Bank Umum Syariah hendaknya dapat merespon dengan baik apabila terjadi kenaikan atau penurunan suku bunga yang berkaitan dengan bank umum konvensional agar dapat menjaga eksistensi dengan meningkatkan nisbah bagi hasil dengan nasabah sehingga dapat bersaing dengan bank umum konvensional.

\section{REFERENCES}

Adetia, D. (n.d.). Pengarub Tingkat Bunga Terbadap Bank Syariah. Https://Www.Kompasiana.Com.

Alim, S. (2014). Analisis Pengaruh Inflasi Dan Bi Rate Terhadap Return on Assets (Roa) 
I-FINANCE: a Research Journal on Islamic Finance Vol.07 No. 01 Juni 2021 http//jurnal.radenfatah.ac.id/index.php/i-finance

Muhammad Arief, Rika Lidyah dan M. Iqbal.............Pengaruh Suku Bunga

Bank Syariah Di Indonesia. Jurnal Ekonomi MODERNISASI, 10(3), 201-219. https://doi.org/10.21067/jem.v10i3.785

Cahyani, W. N., Falah, S., \& Wijayanti, R. Y. (2018). Analisis Pengaruh Roa,Roe,Bopo,Dan Suku Bunga Terhadap Tingkat Bagi Hasil Deposito Mudharabah Pada Perbankan Syariah. MALIA: Journal of Islamic Banking and Finance, 1(1), 105-128. https://doi.org/10.21043/malia.v1i1.3986

Elena, M. (n.d.). Suku Bunga Turun, Bank Atur Strategi Jaga Likuiditas. Https:/ /Finansial.Bisnis.Com.

Farianto, A. (2014). Analisis Pengaruh Return On Asset (Roa), BOPO Dan BI-Rate Terhadap Tingkat Bagi Hasil Deposito Mudharabah Pada Bank Umum Syariah Di Indonesia Tahun 2012-2013. Equilibrium, 2(1), 104-125.

Ikhwal, N. (2016). Analisis Roa Dan Roe Terhadap Profitabilitas Bank Di Bursa Efek Indonesia. Al-Masraf: Jurnal Lembaga Keuangan Dan Perbankan, 1(2), 211-227. http://journal.febi.uinib.ac.id/index.php/almasraf/article/view/57

Kalengkongan, G. (2013). Tingkat Suku Bunga Dan Inflasi Pengaruhnya Terhadap Return on Asset (Roa) Pada Industri Perbankan Yang Go Public Di Bursa Efek Indonesia. Jurnal Riset Ekonomi, Manajemen, Bisnis Dan Akuntansi, 1(4), 737-747. https://doi.org/10.35794/emba.v1i4.2757

Laily, Z. F. dan U. F. (2018). Pengaruh Return On Asset, Return On Equity, Dan Financing To Deposit Ratio Terhadap Tingkat Bagi Hasil Deposito Mudharabah (Pada Bank Umum Syariah Periode 2012-2017). El-Qist, 08(01), 1597-1617.

Lemiyana. (2018). Manajemen Dana Bank. Noer Fikri.

Levia, A., \& Sulasmiyati, S. (2017). Analisis Komparasi Kinerja Perbankan Terbesar Di Indonesia Dan Malaysia (Studi pada Bank Umum di Indonesia dan Malaysia Tahun 2011 â€“ 2015). Jurnal Administrasi Bisnis, 51(2), 40-49.

Nur, M. I., \& Nasir, M. (2014). Pengaruh Kinerja Keuangan Terhadap Tingkat Bagi Hasil Deposito Mudharabah Dan Tingkat Pengembalian Ekuitas Pada Bank Umum Syariah Di Indonesia. Diponegoro Journal of Accounting, 3(3), 1-13.

Nuswandari, C. (2009). Pengungkapan Pelaporan Keuangan Dalam Perspektif Signalling Theory Oleh: Cahyani Nuswandari, SE.Ak Fakultas Ekonomi Universitas Stikubank. Kajian Akuntansi, 1(1), 48-57.

Oktavia Rosana, D. (2018). Pengaruh Dana Pihak Ketiga, Inflasi, Bi Rate, Dan Kurs Terhadap Profitabilitas Perbankan Syariah Di Indonesia Periode 2013-2017 Skripsi Diajukan untuk. Melengkapi Tugas-tugas dan Memenubi Syarat-syarat Guna Memperoleh Gelar Sarjana Ekonomi (S.E) Dalam Ilmu [UIN Raden Intan Lampung]. http:/ / repository.radenintan.ac.id/3956/1/pdf.pdf

Prasetyaningrum, R. I. dan S. (2016). Analisis Return On Equity, Return On Asset, FDR, BOPO Dan Suku Bunga Terhadap Tingkat Deposito Mudharabah (Studi Bank Umum Syariah 2012-2014). Future, 3(2), 125-142.

Ruslizar, \& Rahmawaty. (2016). Pengaruh Tingkat Bagi Hasil Deposito Mudharabah, Financing To Deposit Ratio, Dan Suku Bunga Deposito Terhadap Pertumbuhan Deposito Mudharabah Pada Bank Umum Syariah Di Indonesia. Jurnal Ilmiah Mahasiswa Ekonomi Akuntansi (JIMEKA), 1(2), 84-90.

Sugiyono. (2018). Metode Penelitian (Kuantitatif, Kualitatif dan R\&D). Alfabeta.

Sunaryo, K., \& Isna K, A. (2012). Analisis Pengaruh Return on Asset, Bopo, Dan Suku Bunga Terhadap Tingkat Bagi Hasil Deposito Mudharabah Pada Bank Umum Syariah. Jurnal Ekonomi Dan Bisnis, 11(1), 29-42. 
I-FINANCE: a Research Journal on Islamic Finance Vol.07 No. 01 Juni 2021 http//jurnal.radenfatah.ac.id/index.php/i-finance Muhammad Arief, Rika Lidyah dan M. Iqbal.............Pengaruh Suku Bunga

Syaichu, E. S. Wi. dan M. (2013). Analisis Pengaruh Suku Bunga, Inflasi, Car, Bopo, Npf Terhadap Profitabilitas Bank Syariah. Diponegoro Journal of Management, 2(2), 1-10.

Wahyudi, M. D. (n.d.). Bank Konvensional Vs Bank Syariah, Siapa Yang Lebih Unggul Dalam Segi Sistem Dan Pertumbuban Nasabah? Https://Www.Kompasiana.Com.

Wirawan, J. (n.d.). Suku bunga acuan BI turun: Apa manfaatnya bagi warga biasa? Https://Www.Bbc.Com.

Yoliawan. (n.d.). DPK perbankan syariah naik 20,54\% per Oktober 2017. Https:/ Keuangan.Kontan.Co.Id.

Yudistira, G. (n.d.). ROA menggemuk, rasio profitabilitas bank membaik. Https://Keuangan.Kontan.Co.Id. 